УДК 658.7

\title{
ПЕРЕВАГИ ПУЛІНГОВОЇ СХЕМИ ОРГАНІЗАЦІЇ ОБОРОТУ БАГАТОРАЗОВОÏ ТАРИ
}

\section{ADVANTAGES PULLING SCHEME OF ORGANIZATION MULTIPLE PACKAGING TURNOVER}

\author{
Кобилюх Оксана Ярославівна \\ старший викладач, \\ Національний університет «Львівська політехніка» \\ ORCID: https://orcid.org/0000-0003-1286-1839 \\ Гірна Ольга Богданівна \\ кандидат економічних наук, доцент, \\ Національний університет «Львівська політехніка» \\ ORCID: https://orcid.org/0000-0003-2492-725X
}

\author{
Kobylyukh Oksana, Hirna Olha \\ National University Lviv Polytechnic
}

\begin{abstract}
У статті розкрито основні переваги використання для логістичних операцій багаторазової тари, представлено найбільш доречні сорери використання багаторазової тари. Розкрито сутність поняття «пулінг», окреслено основні елементи використання пулінгової схеми організації обороту багаторазової тари. Розвиток пулінгу в Україні $є$ актуальним питанням, оскільки Україна, є великим сільськогосподарським виробником, зокрема активно розвивається плодоовочевий сегмент, для якого пулінгова схема організації обороту багаторазової тари надзвичайно важлива. Окреслено основні переваги використання пулінгової схеми організації обороту багаторазової тари, як одного із елементів оптимізації логістичних витрат у ланцюгу поставок.
\end{abstract}

Ключові слова: тара, упаковка, пулінг, багаторазова тара, ланцюг поставок.

В статье раскрыты основные преимущества использования для логистических операций многоразовой тары, представлены наиболее подходящие сферы использования многоразовой тары. Раскрыта сущность понятия «пуллинг», обозначены основные элементы использования пуллинговой схемы организации оборота многократной тары. Развитие пуллинга в Украине является актуальным вопросом, поскольку Украина является крупным сельскохозяйственным производителем, в частности, активно развивается плодоовощной сегмент, для которого пуллинговая схема организации оборота многократной тары чрезвычайно важна. Очерчены основные преимущества использования пуллинговой схемы организации оборота многократной тары как одного из элементов оптимизации логистических затрат в цепи поставок.

Ключевые слова: тара, упаковка, пуллинг, многоразовая тара, цепь поставок.

The article reveals the main advantages of using reusable packaging for logistics operations, presents the most relevant areas use of reusable packaging. In logistics, the use of reusable, returnable packaging is a way to improve the environmental performance of the enterprise because the transition to reusable packaging minimizes the use of disposable packaging and, consequently, significantly reduce industrial waste and negative impact on the environment. The advantages of using reusable packaging cover other areas of business, environmental friendliness, this is just one aspect of the transition to the use of reusable packaging and packaging. If we compare reusable packaging with disposable packaging, the use of the latter is appropriate for one-time atypical shipments, only over long distances, if the benefits of returning empty containers are less than its use. A separate area of the organization circulation of reusable packaging is the pooling system, the implementation of which has many advantages and ultimately leads the optimization of logistics costs in the supply chain. The essence of the concept "puling" is revealed, the main elements of using the pulling scheme of reusable packaging organization are outlined. In the puller system, the packaging circulates within a limited number of enterprises in such a way that none of them included in the pool faces the need to purchase additional packaging or the problem of excess packaging in the warehouse. The development pooling in Ukraine is an urgent issue, as Ukraine is a large agricultural producer, in particular, the fruit and vegetable segment is actively developing, for which the pooling scheme of reusable packaging is extremely important. Most domestic companies use pulling in the supply of raw materials and in-plant cycles. Some companies 
use reusable packaging for the export of finished products. The tendencies of recent years regarding the use of the pulling scheme abroad are presented separately. The main advantages using the pulling scheme of reusable packaging turnover as one the elements of optimization of logistics costs in the supply chain are outlined.

Keywords: packaging, packaging, pulling, reusable packaging, supply chain.

Постановка проблеми. Правильний вибір тари в логістиці допомагає заощадити кошти, виконуючи при цьому свою основну фрункцію забезпечення надійності зберігання і транспортування товарів. Відомо, що тара за кратністю використання поділяється на разову та багатооборотну. Інвестиції в багатооборотну тару однозначно приносять фрінансову вигоду, тому компаніям-виробникам або постачальникам логістичних послуг вигідніше й рентабельніше використовувати саме багатооборотну тару [1]. Переваг використання багатооборотної тари багато, наприклад, пластиковий піддон прослужить набагато довше, ніж дерев'яний, а у випадку використання схеми організації повернення тари збірно-розбірні пластикові конструкції значно економлять простір зберігання. Перехід до оборотної тари вигідний для компаній, що мають фрілії по Україні, оскільки це значно здешевлює собівартість товару, адже зменшуються витрати на покупку дерев'яних піддонів та упаковку, які зазвичай включають у вартість самого товару.

Окремим напрямом організації обігу багатооборотної тари є система пулінгу, впровадження якої містить багато переваг і в підсумку призводить до оптимізації логістичних витрат у ланцюгу поставок.

Аналіз останніх досліджень та публікацій. Логістичні аспекти тари та упаковки розглядаються у працях науковців, зокрема, Горбенко О.В., Крикавського Є.В., Кальченко А.Г., Лукінського В.С. [2-5]. Вченими розкрито поняття, види і фуннції тари та упаковки, визначено їх роль та представлено логістику операцій з тарою та упакуванням. Аналіз публікацій науковців дозволяє стверджувати про одностайність думка науковців щодо: важливості тари та упаковки для забезпечення схоронності товару, що в свою чергу забезпечує підвищення якості логістичного сервісу відносно споживачів товарів; гармонізовані типорозмірні ряди упаковки дозволяють знизити логістичні витрати, оскільки забезпечується більш продуктивне використання вантажопідйомності транспортних засобів та складського обладнання, а також робочого часу персоналу; інфрормативність упаковки дозволяє швидко ідентифрікувати товари, прискорити їх пошук і розподіл по замовленнях, місцях зберігання та ін., що дає можливість прискорити вантажопереробку та логістичні цикли в цілому.

Виділення невирішених раніше частин загальної проблеми. Разом з цим, не дивлячись на достатню розробленість питань щодо логістичних операцій з тарою та упакуванням, питання організації обігу багатооборотної тари залишається недостатньо дослідженим. 3 огляду на це, фрормується проблематика дослідження та представлення теоретичних та прикладних аспектів організації обігу багатооборотної тари, зокрема за схемою пулінгу. Організація обороту багаторазової тари за схемою пулінгу на даний час відноситься до інноваційних систем обороту тари багаторазового використання, тому дедалі більше логістичних операторів розглядають ії̈ в якості механізму оптимізації логістичних витрат у ланцюгу поставок.

Формулювання цілей статті визначається як дослідження переваг використання багаторазової тари та запровадження пулінгової схеми в організації обороту багаторазової тари, як механізму оптимізації логістичних витрат у ланцюгу поставок.

Виклад основного матеріалу дослідження. Під тарою багаторазового використання розуміють пластикові та металеві контейнери різної місткості, до неї включають пластикові та дерев'яні палети. Контейнери можуть бути складними, що підвищує зручність у випадку порожнього транспортування, та нескладними, здебільшого вони використовуються у внутрішньозаводських процесах, де складування не є принциповим.

Пластикові і металеві контейнери можна використовувати на великих промислових підприємствах, де застосовується великі контейнери місткістю від $1 \mathrm{~m}^{3}$. Використовувати їх можна як для поставок сировини, так і для вивозу готової продукції - рідких, твердих і навіть хімічних речовин. Контейнери менших розмірів здебільшого використовуються в сегменті FMCG, як у випадку розподілу товарів від оптових складів до точок збуту, так і при викладці товарів у магазинах.

Економічна ефрективність використання багаторазової (багатооборотної) тари обумовлена циклічністю їі застосування у логістиці. Це дозволяє, по-перше, скоротити питомі витрати на одиницю продукції, що перево- 
зиться, по-друге, знизити операційні витрати, пов'язані з обробкою партій вантажів (спростити складські операції і скоротити складські площі, зменшити часові інтервали на вантажно-розвантажувальні роботи, підвищити ефрективність використання простору транспортного засобу).

У логістиці застосування багатооборотної, зворотної тари відноситься до способів покращення екоскладової діяльності підприємства оскільки, перехід на багатооборотну тару дозволяє звести до мінімуму використання одноразової упаковки i, як наслідок, значно скоротити обсяг промислових відходів та негативне навантаження на навколишнє середовище. Переваги використання багатооборотної тари охоплюють й інші сорери діяльності підприємств, екологічність, це лише один 3 аспектів переходу на використання багатооборотної тари і упаковки (табл. 1).
На сьогоднішній день для організації логістичних процесів і зручного транспортування та зберігання товарів дедалі більш популярним стає використання пластикової тари (лотків, ящиків або контейнерів).

На довговічність і окупність багатооборотної тари впливає кілька чинників: її тип, обсяг парку даної тари, кількість циклів, логістичне плече, вартість оренди тари у порівнянні із вартістю одноразової упаковки. Всі вказані параметри складають математичну модель, за допомогою якої і визначається ефективність застосування багатооборотної тари. Виробники багатооборотної тари здебільшого вказують нормативні терміни служби виходячи із 1000 циклів ії збирання й розбирання. Хоча, зазвичай, тара служить набагато довше, зокрема при умові дотримання правил поводження. На думку орахівців окупність багатооборотної тари становить в середньому 2-3 роки.

Переваги використання багатооборотної тари та упаковки

Таблиця 1

\begin{tabular}{|c|c|}
\hline Показник & Умовні позначення \\
\hline $\begin{array}{l}\text { Фінансова } \\
\text { вигода }\end{array}$ & $\begin{array}{l}\text { Інвестиції в багатооборотну упаковку, можуть принести фрінансову вигоду } \\
\text { в середньостроковій і довгостроковій перспективах. Напр., пластиковий } \\
\text { піддон середньої вантажопідйомності служить в } 10 \text { разів довше, ніж } \\
\text { дерев'яний піддон, при використанні всередині компанії, а з часом він може } \\
\text { приносити власний дохід. }\end{array}$ \\
\hline $\begin{array}{l}\text { Додатковий } \\
\text { захист }\end{array}$ & $\begin{array}{l}\text { Оскільки тара багаторазового використання, за своєю природою, } \\
\text { міцна і довговічна, створена щоб витримувати багаторазове використання, } \\
\text { її використання знижує ризик пошкодження продукції при транспортуванні. }\end{array}$ \\
\hline Гігієна & $\begin{array}{l}\text { Для харчової і фрармацевтичної промисловості важливо вибрати тару, } \\
\text { яка легко миється. Пластикові піддони і ящики спеціально розроблені } \\
\text { з гладкими, закритими поверхнями для використання в гігієнічних умовах } \\
\text { і в чистих приміщеннях. }\end{array}$ \\
\hline Перевезення & $\begin{array}{l}\text { Поворотна тара, як правило, складається одна в одну, що скорочує простір } \\
\text { для зберігання і транспортування та пов'язані з цим витрати. }\end{array}$ \\
\hline $\begin{array}{l}\text { Оптимізація } \\
\text { роботи }\end{array}$ & $\begin{array}{l}\text { Одноразова тара і упаковка (картонні коробки або гофротара), вимагають } \\
\text { більших затрат часу для збирання, запаковування, розпакування } \\
\text { і підготовки до утиллізації після використання. }\end{array}$ \\
\hline $\begin{array}{l}\text { Скорочення } \\
\text { утилізації }\end{array}$ & $\begin{array}{l}\text { Переробка гофротари і дерев'яної тари - регулярний і частий процес } \\
\text { на підприємствах. Термін роботи багатооборотної тари, довше і утилізація } \\
\text { мінімізується до одного разу на кілька років. }\end{array}$ \\
\hline Відповідність & $\begin{array}{l}\text { Для роботи з автоматизованими системами, важливі точні розміри і вага } \\
\text { тари. Пластикові піддони і ящики відливаються по заданих параметрах, } \\
\text { це їх робить ідеальними для автоматизованих ліній. }\end{array}$ \\
\hline Відстеження & $\begin{array}{l}\text { Тара багаторазового використання, просто оснащується мітками } \\
\text { і датчиками відстеження, щоб клієнти могли легко контролювати } \\
\text { свій вантаж по всьому ланцюгу поставок. }\end{array}$ \\
\hline $\begin{array}{l}\text { Індивідуальні } \\
\text { рішення }\end{array}$ & $\begin{array}{l}\text { У випадку специффічних вимог до багатооборотної тари, вибір серед } \\
\text { пластикових виробів різноманітний: різний дизайн, колір, матеріал, } \\
\text { додаткові послуги: (лого, маркування та ін.). }\end{array}$ \\
\hline $\begin{array}{l}\text { Захист } \\
\text { навколишнього } \\
\text { середовища }\end{array}$ & $\begin{array}{l}\text { Пластикова тара: багатооборотна, перероблялася, піддається реставрації. } \\
\text { Ці аспекти є вагомими для зниження споживання в виробничих масштабах. }\end{array}$ \\
\hline
\end{tabular}


Якщо порівняти тару багаторазового використання з одноразовою упаковкою, то застосування останньої доречне при разових нетипових відправленнях, винятково на далекі відстані, у випадку коли вигоди від повернення порожньої тари менші ніж від її застосування.

Сфери використання багатооборотної тари різноманітні - це і сировина, і запчастини, і наливні речовини. На практиці тара багаторазового використання застосовується здебільшого у певних сорерах. Найбільш часто у automotive, з метою перевезення компонентів і запчастин для забезпечення виробництва, а також на етапі реалізації. Дуже часто тара багаторазового використання присутня в ритейлі, а також у будівельній, харчовій промисловості, фрешн-індустрії. Також слід відзначити насртохімічну галузь, де тара застосовується при транспортуванні рідких середовищ, каучуку і інших полімерів.

Пулінг багатооборотної тари визначають як спеціально розроблений замкнутий логістичний цикл, основою якого $є$ надання в довготривалу оренду різних видів тари та надання також супутнього сервісу (рис. 1). Супутній сервіс може містити подачу їі на навантаження, транспортування тари, складування, очищення, облік, ремонт й схожі операції, що окремо узгоджено у договорі пулінгу.

Сам підхід не новий. Відомо, що під час другої світової війни армія США доставляла величезну кількість вантажів в Австралію для забезпечення військових дій в Тихоокеан- ському регіоні проти Японії. Після завершення військових дій залишилася велика кількість дерев'яних палет, які були викуплені одним із заповзятливих громадян для подальшого їх надання в оренду. Так виник перший в світі пулінговий оператор СНEP - на сьогоднішній день, один з глобальних лідерів пулінгу палет і контейнерів [8].

Схема пулінгової системи має такий вигляд - логістичний оператор закуповує тару, акумулює кошти необхідні для ії обслуговування і організації логістики і надалі передає тару виробнику продукції в оренду. Останній застосовує тару при упакуванні своєї продукції і доставці ії у торговельні мережі. Торговельні мережі, не здійснюючи перевантаження, виставляють на торгівельні полиці товар у пулінговому контейнері (в якому товар надійшов). Після реалізації продукції, логістичний оператор вилучає свою тару 3 торговельної мережі, проводить ії санітарну обробку і заново надає їі виробнику. Традиційно пулінговий ящик - це пластиковий, розкладний, багаторазовий ящик, який можна швидко скласти і розкласти, а у зібраному стані він значно економить місце при транспортуванні та зберіганні. Пулінг (від слова «пул» - об'єднання) - це інноваційна система обороту тари багаторазового використання, використання якої дозволяє оптимізувати логістичні витрати у ланцюгу поставок. В пулінговій системі тара циркулює у межах обмеженого кола підприємств таким
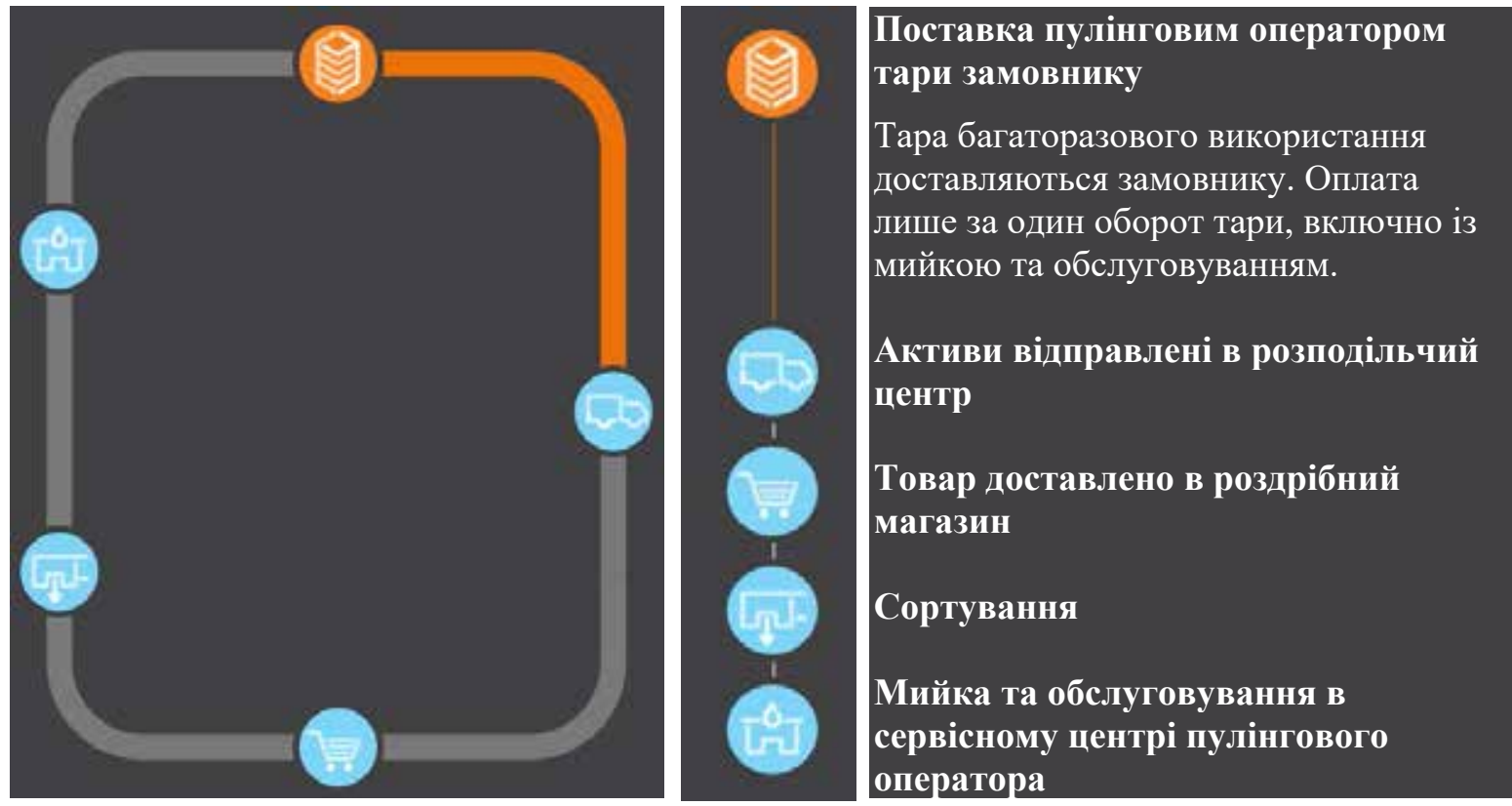

Рис. 1. Схема пулінгу багатооборотної тари 
чином, що жодне з них, яке увійшло в пул, не зіштовхується ні 3 необхідністю придбання додаткової упаковки, ні з проблемою надлишків упаковки на складі. Основною перевагою застосування пулінгової системи $€$ те, що приховані витрати стають явними, і при цьому знижуються загальні витрати (рис. 2).

Використання тари за системою пулінгу призводить до зменшення собівартості продукції. Вартість одноразової тари (пластик, картон) зазвичай, на 20-70\% більша ніж вартість оренди тари за пулінговою схемою. В зв'язку 3 тим, що пулінгова тара має однакову вагу, фрормується на піддонах згідно заданих габаритних розмірів, безперешкодно встановлюється на стелажі, та у інші місця зберігання, зменшується час на приймання і відбракування прийнятих матеріалів (товарів) на 20\%. Вартість орендованої тари не вища, ніж вартість придбання одноразової упаковки. Крім того, зменшується і операційна діяльність 3 тарою, напр., отримавши тару у вказаний час, компанія збирає в неї урожай, і доставляє його на РЦ торговельної мережі, і все.

Окремо слід відзначити тенденції останніх років щодо використання схеми пулінгу закор- доном. Представимо результати опитування, яке проводилося в США у 2020 р., участь у якому взяло 146 компаній. На питання «Ваша компанія орендує, планує орендувати чи користується послугами компаній з ремонту/ відновлення піддонів?» 75\% питаних компаній дали негативну відповідь, відповідно відбулося зменшення в порівнянні із 2018 р., коли результати становили 84\% (рис. 3). Ствердну відповідь щодо користування системою відновлення піддонів/ремонту дали $16 \%$ опитаних компаній, що більше в порівнянні з 2018р. 5\%. Послугою оренди піддонів із деревини користуються 9\% опитаних, що менше ніж у 2018 р. (11\%).

За результатами опитування, на даний час лише 6\% опитаних компаній зацікавлені в ймовірній участі у пулінгових системах впродовж цього року, тобто готові взаємодіяти із операторами по відновленню та ремонту піддонів. Віддати перевагу тільки конкретній із означених систем готові 13\% компаній. Проте багато компаній ще мають побоювання, оскільки 33\% компаній не готові до співпраці (для порівняння 43\% в 2018 р.), а 29\% опитаних компаній визначають їх застосування малоймовір-

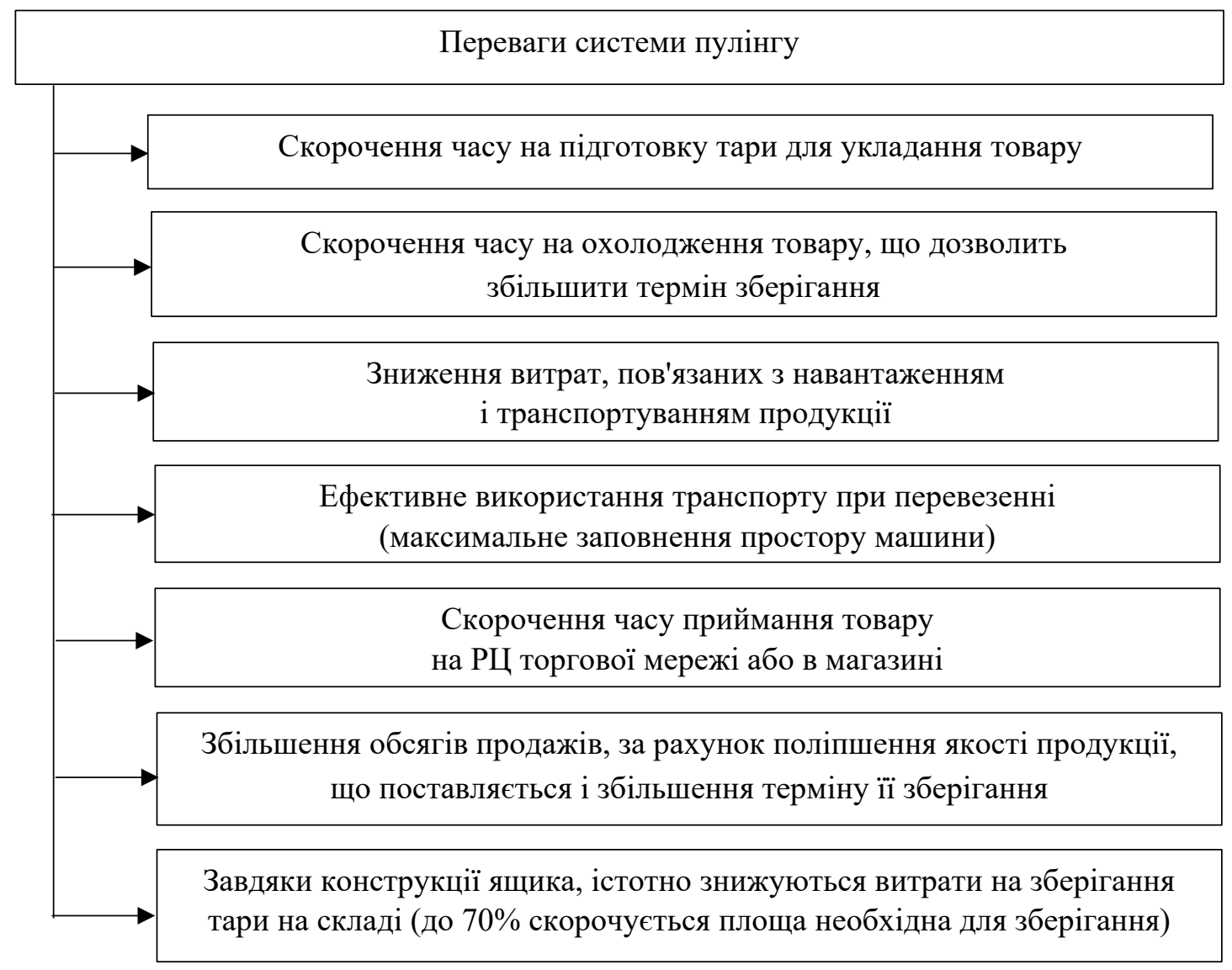

Рис. 2. Переваги використання системи пулінгу 


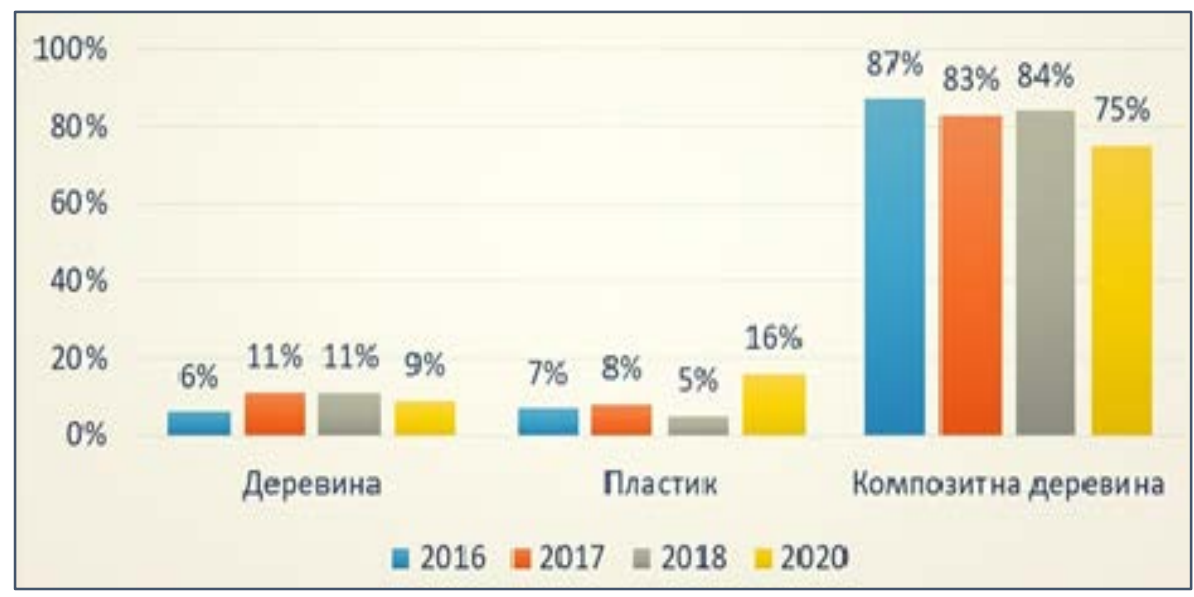

Рис. 3. Результати відповідей на питання

«Ваша компанія орендує, планує орендувати чи користується послугами компаній з ремонту/відновлення піддонів?»

Джерело: [10]

ним. Слід відзначити низьку інфрормованість опитаних компаній, адже їх 19\% взагалі не ознайомлені ні з пулінговими системами, ні із системами по відновленню/ремонту піддонів. Отже, зацікавленість щодо переходу на схему пулінгу у компаніях за останні три роки зросла, хоча не небагато, причиною чого може бути їх низька інфрормованість.

В європейських країнах впродовж останніх 30-ти років пулінгові схеми стали основою в організації обороту багаторазової тари. На даний момент пулінгові компанії $€$ на логістичних ринках більшості розвинених країн. Найбільші 3 операторів працюють на кількох континентах із парком багаторазової тари більше 100 млн. шт., зокрема серед них слід виділити такі:

1) Deutsche Paletten Logistik - на ринку 3 1992 р., 20 представництв в Європі, щорічний приріст обороту тари 9,5\% (або 500 млн. ящ. оборотів) у рік, парк тари 33 млн. піддонів (включаючи EUR, половину Düsseldorfer, гігієнічні піддони $\mathrm{H} 1$ ).

2) Polymer Logistics - на ринку з 1994 р., офріси-Австралія, США, Ірландія, Іспанія, Німеччина, Франція, щорічний приріст обороту тари 8\% (або 500 млн. ящ. оборотів), парк тари 36,5 млн. ящиків. Станом на жовтень 2021 р., компанія з моменту початку випуску RPC у 2000 р. унеможливила надходження в ланцюг поставок 1,55 млн. тонн гофроупаковки.

3) IFCO Systems - на ринку 31998 р., 40 представництв по всьому світу, 2000 млн. ящ. оборотів в рік, парк тари 140 млн. ящ.

4) Brambles - керуюча компанія IFCO i CHEP - на ринку з 1875 р., представництва в 50 країнах світу [6].
Пулінг багатооборотної тари з'явився в Україні в кінці 2000-х років. Найбільшими операторами вітчизняного ринку послуг з оренди оборотної пластикової тари на даний час $€$ такі:

1) ТзОВ «Натеко Логістика» - заснована в 2012 р. На даний момент компанія пропонує в оренду складні контейнери власного виробництва [11]. Конструкція контейнерів забезпечує збереження свіжих продуктів під час транспортування і дозволяє максимально використовувати обсяг фрургону та складу. Партнерами та клієнтами компанії $€$ торгові мережі - «Сільпо», «АШАН», «АТБ», «METRO», «FOZZY», «ФOPA», та національні виробники і постачальники.

2) ПП «Бекрістон» - заснована у 2008 р. У 2010 р. компанія виділила послугу прокату тари - як окремий бізнес-проект, для чого було створено підприємство «Українська пулінгова система», діяльність якої спрямована на забезпечення українського постачальника та виробника багаторазовою оборотною тарою для поставок у торговельні мережі України [12]. За перший рік діяльності у оборотній тарі «УПС» було перевезено 300 тис. тонн продукції, загальний парк обігової тари становив 800 тис. од. У 2013 р. компанія розширила пулінговий бізнес, перейшовши до комплексного забезпечення логістичних процесів різно профрільною оборотною тарою (ящики, контейнери, палети, ролкейджі). Партнерами та клієнтами компанії $€$ національні торгові мережі, а також виробники та постачальники плодоовочевої продукції України.

3) ТзОВ «Юг Логистик Групп» - заснована у 2016 р. Компанія пропонує прокат полімер- 
ної тари ізраїльського, польського, німецького та українського виробництва. Партнерами та клієнтами компанії $€$ Сільпо Фуд, АТБ, ВПК «Агро», Ніко-Юг, фрермерське господарство Ранет та ін. [13].

Більшість вітчизняних підприємств використовує пулінг при поставках сировини та матеріалів і у внутрішньозаводських циклах [14]. Окремі компанії застосовують пулінг багатооборотної тари при експорті готової продукції. У цьому випадку використання багатооборотної тари відбувається у зв'язку із стандартами головного офрісу (материнської компанії), або на вимогу іноземних партнерів, які закуповують продукцію. Це дозволяє знизити собівартість продукції і зменшити обсяги утилізованої упаковки. Останнє особливо актуальне для компаній, що декларують екологічно чисту логістику.

Висновки. Все вищевказане розкриває перспективи розвитку ринку тари багатооборотного використання. Загалом можна прогнозувати зростання обсягів використання полімерних багатооборотних ящиків, насамперед складних, підприємствами харчової промисловості, оскільки у них високі вимоги щодо забезпечення харчової безпеки. В перспективі виробники поступово відійдуть від використання дерев'яних та гофрокартонних ящиків i нададуть перевагу застосуванню багаторазової тари.

Актуальність використання пулінгу при організації обороту багаторазової тари пояснюється акцентуванням в останній час уваги підприємців не лише на споживчій упаковці, а й аналізі оборотної тари, адже раціональний вибір тари дозволяє заощадити немалі кошти, забезпечити надійність ланцюга поставок, тобто призвести до економної логістики. Використання зворотної тари дозволить мінімізувати використання одноразової картонної упаковки, що автоматично призведе до скорочення логістичних витрат, підвищить рівень збереження від механічних пошкоджень, не кажучи вже й про екоаспект - зниження навантаження на навколишнє середовище. Застосування пудлінгу багатооборотної тари особливо ефективне в циклічних логістичних схемах - при транспортуванні продукції у торговельні мережі, а також на коротких плечах із великою кількістю циклів, тобто при побудові локальної розподільної мережі.

\section{СПИСОК ВИКОРИСТАНИХ ДЖЕРЕЛ:}

1. Горбенко О.В. Пакування і зберігання вантажів в ланцюгах постачань. Економіка та управління на транспорті. 2017. Випуск 4. С. 25-40.

2. Горбенко О.В. Логістика : навч. посібник. Київ, 2014. 315 с.

3. Кальченко А.Г. Логістика : підручник. Київ, 2006. 284 с.

4. Крикавський $€$. Логістика для економістів : підручник. Львів, 2014. 476 с.

5. Лукінський В.С., Лукінський В.В., Плетньова Н.Г. Логістика та управління ланцюгами постачань. Москва, 2018. 359 с.

6. Чому варто перейти на багатооборотну тару? URL: https://ssk.ua/ua/blog/pochemu-stoit-perejti-namnogooborotnuyu-taru-509 (дата звернення: 18.11.2021).

7. Многооборотная полімерна тара - практично і економічно. URL: https://www.packaging.com.ua/ content/4714 (дата звернення: 19.11.2021).

8. Пакування і зберігання вантажів: стандарти, пулінг, і трохи історії. URL: https://logistics-ukraine.com/ 2018/02/15 (дата звернення: 18.10.2021).

9. 10 причин почему стоит перейти на многооборотную тару. URL: https://admirel.com.ua/interesno-znat/ stati/68-10-prichin-pochemu-stoit-perejti-na-mnogooborotnuyu-taru (дата звернення: 17.11.2021).

10. Річний звіт: оцінювання ринку піддонів 2020 року. URL: https://logistics-ukraine.com/2021/01/28/(дата звернення: 21.11.2021).

11. HATEKO. URL: https://nateco.com.ua/benefits/index (дата звернення: 22.11.2021).

12. Бекрістон. URL: https://container-rent.com.ua/ (дата звернення: 21.11.2021).

13. ЮГ ЛОГИСТИК ГРУП. URL: https://slg-pooling.com/ (дата звернення: 17.11.2021).

14. Пулинг как средство экономии. URL: https://sostav.ua/news/2010/03/22/8/30292 (дата звернення: 17.11.2021).

\section{REFERENCES:}

1. Gorbenko O.V. (2017) Pakuvannya i zberihannya vantazhiv v lantsyuhakh postachan [Packing and storage of goods in supply chains]. Economics and management of transport, 4, 25-40. (in Ukrainian) 
2. Gorbenko O.V. (2014) Lohistyka [Logistics]. Kyiv, 315. (in Ukrainian)

3. Kalchenko A.G. (2006) Lohistyka [Logistics]. Kyiv, 284. (in Ukrainian)

4. Krykavsky E. (2014) Lohistyka dlya ekonomistiv [Logistics for economists]. Lviv, 476. (in Ukrainian)

5. Lukinsky V.S., Lukinsky V.V., Pletnyova N.G. (2018) Lohistyka ta upravlinnya lantsyuhamy postachan [Logistics and supply chain management]. Moscow, 359. (in Russian)

6. Why switch to reusable packaging? Retrieved from: https://ssk.ua/en/blog/pochemu-stoit-perejti-na-mnogooborotnuyu-taru-509 (accessed 18 November 2021). (in Ukrainian)

7. Reusable polymer packaging - practical and economical. Retrieved from: https://www.packaging.com.ua/ content/4714 (accessed 19 November 2021).

8. Packing and storage of goods: standards, pulling, and a little history. Retrieved from: https://logistics-ukraine.com/ 2018/02/15 (accessed 18 October 2021). (in Ukrainian)

9. 10 reasons why you should switch to reusable packaging. Retrieved from: https://admirel.com.ua/ interesno-znat/stati/68-10-prichin-pochemu-stoit-perejti-na-mnogooborotnuyu-taru (accessed 17 November 2021). (in Ukrainian)

10. Annual report: pallet market assessment in 2020. Retrieved from: https://logistics-ukraine.com/2021/01/28/ (accessed 21 November 2021). (in Ukrainian)

11. NATEKO. Retrieved from: https://nateco.com.ua/benefits/index (accessed 22 November 2021). (in Ukrainian)

12. Becriston. Retrieved from: https://container-rent.com.ua/ (accessed 21 November 2021). (in Ukrainian)

13. SOUTH LOGISTICS GROUPS. Retrieved from: https://slg-pooling.com/ (accessed 17 November 2021). (in Ukrainian)

14. Pulling as a means of saving. Retrieved from: https://sostav.ua/news/2010/03/22/8/30292 (accessed 17 November 2021). (in Ukrainian) 